\title{
ANALISA TERHADAP PENGEMBANGANGAN OBYEK WISATA DI MATA MAHASISWA LUAR JAWA SEBAGAI WISATAWAN DI DAERAH ISTIMEWA YOGYAKARTA
}

\author{
Wisnu Hadi \\ Jurusan Perhotelan Universitas Bina Sarana Informatika \\ wisnu.wsh@bsi.ac.id
}

\begin{abstract}
ABSTRAK
Pengembangan pariwisata di wilayah Indonesia mempunyai tujuan untuk meningkatkan pendapatan nasional dan daerah yang memiliki obyek wisata tersebut. Sebagai destinasi wisata Provinsi Daerah Istimewa Yogyakarta selalu menjadi wilayah selalu menjadi tujuhan wisatawan domestik dan internasional sehingga pertumbuhan wisatawan setiap tahun meningkat seiring dengan munculnya obyek wisata baru sehingga menjadi alternatif kunjungan setelah obyek wisata sudah ada. Sebagai kota pendidikan Provinsi Daerah Istimewa Yogyakarta mempunyai potensi mahasiswa dan pelajar yang belajar di wilayah ini sebagai wisatawan yang selalu menggunakan waktunya untuk berkunjung sebagai wisatawan ke berbagai obyek wisata yang dimiliki provinsi ini. Dalam penelitian yang bersifat deskriptif kualitatif ini peneliti ingin mengetahui penilaian dari mahasiswa yang belajar di Provinsi Daerah Istimewa Yogyakarta tentang pengembangan wisata di berbagai obyek wisata di wilayah ini yang mereka telah kunjungi. Mahasiswa luar jawa sebagai obyek penelitian menilai bahwa pengembangan wisata sudah dinyatakan baik hal ini dikaitkan dengan pelayanan dan kepuasaan selama mengunjungi obyek wisata di Provinsi Daerah Istimewa Yogyakarta. Aspek sarana-prasarana yang ada di obyek wisata dinilai sudah baik, kemudian aspek rasa aman dan nyaman juga dinyatakan memuaskan ditunjang dengan harga makanan, tiket masuk, souvenir juga dijawab memuaskan. Mahasiswa luar jawa sebagai wisatawan menyatakan sangat berkesan dan ini menjadi pengalaman positif baginya dan akan diceritakan kepada orang lain sehingga menjadi referensi untuk kembali berkunjung ke obyek wisata di Provinsi Daerah Istimewa Yogyakarta.
\end{abstract}

\section{ABSTRACT}

Development of tourism in the territory of Indonesia has a purpose to increase national and regional income that has these tourism objects. As a tourist destination in Yogyakarta Special Region has always been a region always a destination for domestic and international tourists so that the growth of tourists every year increases along with the emergence of new tourism objects so that it becomes an alternative visit after the tourism object already exists. As a city of education, the Special Region of Yogyakarta Province has the potential of students and students studying in this region as tourists who always use their time to visit as tourists to various tourism objects owned by the province. In this descriptive qualitative research researchers want to know the assessment of students who study in Yogyakarta Special Region Province about the development of tourism in various tourist attractions in this region that they have visited. Students outside Java as the object of the study considered that the development of tourism had been declared good. This was related to service and satisfaction while visiting tourism objects in the Special Province of Yogyakarta. Aspects of existing facilities in tourism objects are considered to be good, then aspects of security and comfort are also satisfactorily supported by satisfying food prices, entrance tickets, souvenirs. 
Students outside Java as tourists said it was very impressive and this became a positive experience for him and will be told to others so that it becomes a reference for returning to visit attractions in the Special Province of Yogyakarta.

\section{PENDAHULUAN}

Daerah Istimewa Yogyakarta sebagai daerah tujuan wisata setelah kedua sebelum Pulau Bali memiliki banyak destinasi wisata yang sangat popular secara nasional dan internasional. Era industri 4.0 ditandai dengan strategi-strategi dari masing-masing daerah untuk mengenalkan obyek wisata agar banyak dikunjungi wisatawan khususnya wisatawan asing. Mereka berlomba-lomba menawarkan keunggulan masing-masing obyek wisata yang ada didaerahnya.

Sebagai kota budaya dan kota pendidikan, Provinsi Yogyakarta selalu menjadi tujuan para pelajar untuk menimba ilmu di kota yang mempunyai tempat bersejarah sehingga menjadikan Yogyakarta sebagai kota perjuangan dimasa revolusi kemerdekaan Indonesia saat itu. Pemerintah pusat dalam hal ini Kementerian Pariwisata menjadikan Yogyakarta dengan berbagai obyek wisata yang ada sebagai bagian Kawasan Strategis Pariwsata Nasional (KSPN) dimana obyek-obyek wisata meliputi Candi Borobudur, Candi Prambanan dan Ratu Boko dan Keraton Yogyakarta sehingga perlu dikembangkan serta dipasarkan untuk menarik devisa negara nasional maupun daerah.

Strategi pemasaran selalu dilakukan oleh stakeholder yang ada di Yogyakarta dalam hal ini pemerintah, masyarakat dan swasta, mereka selalu melakukan usaha untuk mengenalkan obyek wisata yang ada didaerah masin-masing. Peran media elektronik seperti internet sangat memudahkan untuk mengenalkan obyek wisata yang selama ini belum terakses secara nasional pelan-pelan menjadi terkenal secara nasional dan internasional. Faktor inilah yang menjadikan banyak pelajar dari luar Yogyakarta khususnya luar pulau Jawa ingin menimba ilmu di kota pendidikan sekaligus kota Budaya yaiyu Yogyakarta.

Obyek wisata di Yogyakarta sangatlah lengkap dari wisata alam pegunungan, gunung api sampai wisata pantai yang membentang dari ujung barat Kabupaten Kulon Progo sampai timur di Kabupaten Gunung Kidul. Wisata pendidikan dan sejarah seperti keraton dan museum menjadikan kota Yogyakarat sangat cocok untuk wisata pendidikan dan sejarah.Setiap hari banyak informasi tentang obyek wisata baru terutama wisata alam menjadikan referensi untuk berwisata semakin bertambah.

Keberhasilan pengelolaan wisata tidak hanya tergantung pada pemerintah daerah atau propinsi, kabupaten/kota sampai desa namun masyarakatnya juga harus sadar bahwa pengembangan wisata yang dimilikinya juga dikelola bersama-sama. Kelompok sadhar wisata banyak tumbuh dan berkembang seiring dengan obyek wisata semakin banyak wisatawan yang berkunjung ke daerahnya. Kesan dan pesan dari wisatawan baik wisata daerah, nasional dan internasional setelah berkunjung menjadikan penilaiaan tentang kepuasaan wisatawan terhadap faktor-faktor yang ada di obyek wisata tersebut.

Seperti penilaiaan terhadap obyek wisata di Yogyakara yang sudah dikunjungi para mahasiswa dari luar Yogyakarta khususnya luar pulau Jawa menilai kesan dan pesan dari factor-faktor yang menarik mereka berkunjung di obyek wisata tersebut. Kesan dan pesan tersebut menarik untuk dianalisis sebagai penelitian terhadap pengembangan wisata yang ada di wilayah Yogyakarta. Mahasiswa luar Yogyakarta menjadikan obyek penelitian untuk menilai keadaan atau kondisi wisata masing-masing tempat yang pernah dikunjungi. 


\section{LANDASAN TEORI}

\section{Pariwisata}

Pariwisata jika diterjemahkan ke dalam berbagai bahasa didunia secara pengertian sempit yaitu: "Perjalanan yang dilakukan bukan untuk komersil, tetapi untuk istirahat, kesehatan, pemuasan hasrat mengetahui tempat-tempat dan rakyat asing".

Sedangkan menurut Undang-undang Pemerintah Nomor 10 Tahun 2009 tentang Kepariwisataan, bahwa pengertian pariwisata adalah berbagai macam kegiatan wisata dan didukung berbagai fasilitas serta layanan yang disediakan oleh masyarakat, pengusaha, pemerintah dan Pemerintah Daerah.

Menurut E.Guyer yang dikutip oleh Pendit (1986) beliau merumuskan Pariwisata sebagai arti modern bahwa Pariwisata adalah gejala jaman sekarang, yang didasarkan atas kebutuhan dan kesehatan dan pergantian hawa, penilaian yang sadar dan menumbuh terhadap keindahaan alam, kesenangan dan kenikamatan alam semesta dan pada khususnya disebabkan oleh bertambahnya pergaulan berbagai bangsa dan kelas dalam masyarakat manusia sebagai hasil perkembangan perniagaan, industri dan perdagangan serta penyempurnaan alat-alat pengangkutan.

\section{Motivasi Wisata}

Motivasi atau dorongan dalam berwisata dapat dikatakan sebagai keinginan untuk melepaskan diri sehingga menjadi pendorong untuk membuat orang melakukan perjalanan di lingkungan baru. Menurut Iso Ahola dalam Burton (1995) yang merangkum pendapatnya bahwa pariwisata merupakan kegiatan untuk melepaskan diri dari keadaan-keadaan sekitar dan keinginan untuk mencapai hal-hal tertentu seperti :

1. Keinginan Untuk Melepaskan Diri

Adapun kegiatan-kegiatannya untuk melepaskan diri meliputi :

a. Dari lingkungan pribadi (masalah pribadi, kegagalan)

b. Dari lingkungan antar manusia (sosial). Misalnya, hubungan dengan kerabat atau rekan kerja, teman dan lainnya.

2. Keinginan Untuk Mendapatkan

a. Kepuasaan batin (beristirahat, mendapat pengalaman menarik)

b. Kepuasaan sosial (interaksi sosial yang lebih baik, menambah teman)

Dengan demikian seorang wisatawan memiliki motivasi berbeda-beda (misalnya, ingin beristirahat dan beraktivitas disaat yang sama). Sehingga wisatawan dapat saja ingin melakukan berbagai macam kegiatan di satu tempat saja.

\section{Potensi Wisata}

Sebuah potensi wisata akan menjadi daya tarik wisata, menurut Gamal Suwantoro (1997) bahwa daya tarik wisata merupakan potensi yang menjadi pendorong kehadiran wisatawan ke suatu daerah tujuan wisata.

Suatu daerah wisata agar menjadi daerah tujuan wisata perlu dirancang secara professional sehingga menjadi potensi wisata yang prospeknya kedepan dapat berkembang lebih maju dan besar. Obyek wisata akan menjadi daya tarik wisata apabila ada sumberdaya yang menimbulkan rasa senang, indah, nyaman dan bersih. Selain itu harus ada sarana-prasarana penunjang untuk melayani para wisayawan yang hadir serta mempunyai daya tarik tinggi karena keindahaan alam berupa pegunungan, sungai, pantai, hutan adanya ciri khusus atau spesifikasi yang bersifat langka, memiliki nilai khusus dalam bentuk atraksi kesenian, upacara dapat dan nilai luhur yang terkandung dalam suatu obyek wisata.

\section{Obyek wisata}

Pengertian objek dan daya tarik wisata menurut undang-undang Kepariwisataan Nomor 9 Tahun 1990, yaitu Objek dan daya tarik wisata terdiri atas :

1. Objek dan daya tarik wisata ciptaan Tuhan Yang Maha Esa, yang berwujud keadaan alam, serta flora dan fauna.

2. Objek dan daya tarik wisata hasil karya manusia yang berwujud museum, peninggalan purbakala, peninggalan 
sejarah, seni budaya, wisata agro, wisata tirta, wisata buru, wisata petualangan alam, taman rekreasi, dan tempat hiburan.

Dalam bukunya Marpaung (2002, hlm. 78) objek wisata adalah suatu bentukan atau aktivitas yang berhubungan, yang dapat menarik minat wisatawan atau pengunjung untuk dapat datang kesuatu tempat/daerah tertentu. Selain itu Marpaung juga menerangkan bahwa terdapat dua kategori objek wisata, yaitu :

1. Objek wisata alam

2. Objek wisata sosial budaya

\section{Pengertian Industri Pariwisata}

Pariwisata bagi suatu negara telah menjadi industri yang menjadi andalan untuk pemasukkan pendapat negaranya sehingga pemerintah menjadi pariwisata sebagai bidang dalam prioritas pembangunannya

Setiap orang mendengar kata industri, persepsi dari kebanyakan orang adalah suatu bangunan pabrik dengan segala perlengkapannya yang mempunyai cerobong asap dengan menggunakan mesin dan proses produksinya. Demikianlah gambaran industri pada umumnya, tetapi industri pariwisata jauh berbeda dengan itu (Yoeti, 1996, hlm. 1).

Pengertian dari industri pariwisata adalah kumpulan usaha pariwisata yang saling terkait dalam menghasilkan barang / dan jasa bagi pemenuhan kebutuhan wisatawan pada penyelenggara pariwisata (Ismayanti, 2010, hlm. 19). Industri pariwisata dalam kumpulan dari berbagai macam perusahaan yang secara bersama-sama menghasilkan barang dan jasa (goods and service) yang dibutuhkan oleh wisatawan traveller pada umumnya selama mereka melakukan perjalanan dari tempat asal ke tempat asal ke arah tujuannya. Industri pariwisata merupakan kegiatan bisnis yang berhubungan langsung dengan kegiatan wisata sehingga tanpa keberadannya, pariwisata tidak dapat berjalan dengan baik.

\section{Strategi Pengembangan Wisata}

Suatu obyek wisata menjadi destinasi wisata yang selalu menarik maka perlu dikembangkan sehingga potensi yang ada dapat digali sehingga pendapat daerahnya dapat meningkatkan pertumbuhan ekonomi warganya. Strategi pengembangan sangat diperlukan agar destinasi wisata dapat menjadi lebih besar dan maju.

Menurut Rangkuti (2003, hlm. 3), menjelaskan tentang strategi pengembangan bahwa strategi merupakan kegiatan perusahaan untuk mencari kesesuaian antara kekuatan-kekuatan internal perusahaan dan kekuatan-kekuatan eksternal (peluang dan ancaman) suatu pasar. Adapun kegiatannya meliputi pengamatan secara hati-hati terhadap persaingan, peraturan tingkat inflasi, siklus bisnis, keunggulan, dan harapan konsumen serta faktor-faktor lain yang dapat mengidentifikasi peluang dan ancaman.

Sedangkan menurut Yoeti (2005, hlm. 22) menyatakan bahwa dalam perencanaan strategis suatu daerah tujuan wisata dilakukan analisis lingkungan dan analisis sumber daya. Dengan demikina tujuan analisis ini tidak lain adalah untuk mengetahui dan menidentifikasi sumber daya utama, terutama mengenai kekuatan (strength) dan kelemahan (weakness) organisasi atau lembaga yang bertanggung jawab terhadap pengembangan pariwisata di daerah tujuan wisata tersebut.

\section{METODE}

Penelitian masalah analisis penilaiaan pengembangan obyek wisata dari mahasiswa luar Jawa terhadap obyek wisata yang ada di Daerah Istimewa Yogyakarta peneliti menggunakan metode diskriptif kualitatif. Metode ini digunakan untuk mengetahui gambaran atau lukisan secara sistematis dan akurat mengenai fakta-fakta, sifat-sifat serta hubungan antar fenomena yang diselidiki.

Sedangkan untuk analisa data peneliti menggunakan analisis disktiptif kualitatif yaitu dengan memberikan ulasan atau interpretasi terhadap data yang diperoleh sehingga menjadi lebih jelas dan bermakna dengan sekedar angka-angka. 
Sedangkan teknik pengumpulan data dari sumber data primer dan sekunder dimana data primer adalah informasi yang diperoleh dari sumber-sumber primer yaitu yang asli, informasi dari tangan pertama atau responden (Wardiyanta, 2006, hlm. 28). Penggunaan data sekunder ini dapat menguntungkan bagi penulis karena dapat menghemat waktu, tenaga dan dana.

Untuk mendapatkan hasil penelitian yang mendekati kebenaran maka digunakan instrumen sebagai berikut:

\section{Wawancara langsung}

Metode wawancara adalah proses tanya jawab dalam penelitian yang berlangsung secara lisan. Penulis melakukan wawancara terhadap sejumlah mahasiswa yang telah satu tahun belajar atau kuliah di Yogyakarta dan pernah berkunjung berbagai obyek wisata di wilayah Yogyakarta.

\section{Kuesioner}

Kuesioner merupakan alat pengumpulan data dengan membuat daftar pertanyaan yang diisi oleh wisatawan yang mayoritas adalah mahasiswa yang telah berkunjung di berbagai obyek wisata di wilayah Yogyakarta.

\section{Studi Pustaka}

Studi Pustaka dilakukan untuk mencari dan mendapatkan data-data yang bersifat teoritis dan berhubungan dengan penelitian yang sedang dilakukan. Dengan mempelajari literatur-literatur, dan sumber-sumber lainnya dari internet yang berhubungan dengan penelitian. Pengumpulan data kepustakaan dilakukan terhadap data dan informasi dalam bentuk buku, laporan hasil penelitian dan sumber lainnya.

Penelitian dilakukan kepada mahasiswa yang kuliah di Yogyakarta dengan menyebarkan angket di kampus atau perguruan tinggi mereka belajar untuk mengisi angket yang telah disediakan oleh peneliti. Penelitian dilakukan selama 1 Minggu pada Bulan Juli 2018

Analisis data yang digunakan dalam penelitian ini adalah analisis deskriptif, kualitatif yang pengujiannya bertitik tolak dari data yang telah terkumpul kemudian dilakukan penarikan kesimpulan. Untuk analisa data peneliti menggunakan metode statistik deskriptif yang berbentuk tabeltabel frekuensi. Data kualitatif dan kuantitatif yang terkumpul ditabulasi, diklasifikasi, diolah dan dianalisis kemudian diinterpretasikan untuk menentukan kesimpulan dari pengembangan obyek wisata di wilayah Yogyakarta.

\section{HASIL DAN PEMBAHASAN}

Provinsi Daerah Istimewa Yogyakarta memiliki keistimewaan dibandingkan provinsi yang lain dimana berdasarkan bentang alam, wilayah Yogyakarta di kelompokkan menjadi empat satuan fisiografi, yaitu satuan fisiografi Gunung Merapi, satuan fisiografi pegunungan selatan atau pegunungan seribu, satuan fisiografi pegunungan Kulon Progo dan satuan fisiografi dataran rendah. Luas wilayah Provinsi Daerah Istimewa Yogyakarta adalah 3.185,80 $\mathrm{km}$ persegi meski luas wilayah kecil namun potensi daerah yang ada didalamnya sangat besar. Dengan potensi wisata alam berupa gunung dan lautan sangat menarik wisatawan dari dalam dan luar Yogyakarta.

Secara georafis, DIY diuntungkan dengan jarak lokasi wisata obyek wisata yang mudah dijangkau oleh wisatawan menggunakan sarana kendaraan bermotor. Selain itu Yogyakarta mempunyai banyak wisata minat-minat khusus yang ditawarkan kepada wisatawan seperti wisata alam dan wisata petualangan. Yogyakarta di ujung utara disuguhhi panorama Gunung Merapi dengan ketinggian 9738 kaki dan masih aktif di dunia ini. Kemudian disisi selatan wisatawan dapat menyaksikan bentangan laut selatan yang mempunyai panorama yang indah tidak duanya. Kemudian sisi timur Yogyakarta mempunyai potensi candicandi yang masih terpelihara dengan baik dan menjadi saksi sejarah peradaban budaya pada jaman Mataram Hindu. Kompleks candi Prambanan dan Ratu Boko sangat 
menarik wisatawan daerah dan nasional serta internasional.

Sejak tahun 2008 Provinsi Daerah Istimewa Yogyakarta dicanangkan sebagai kota Pariwisata berbasis budaya dimana pengembangan pariwisata disesuaikan dengan potensi yang ada dan berpusat pada budaya yang selaras dengan sejarah dan budaya Keraton Yogyakarta Hadiningrat. Pemerintah Yogyakarta telah melakukan rencana untuk mendukung pelaksanaan program ini dari pengembangan dan peningkatan kuanitas serta kualitas fasilitas, memperbanyak event-event wisata, seni dan budaya, sampai ke optimalisasi pemasaran program.

Potensi wisata yang dimiliki Provinsi Yogyakarta menjadi daya tarik para pelajar atau siswa yang ingin belajar di Yogyakarta sehingga predikat kota Pendidikan melekat di kota ini. Jumlah mahasiswa yang berjumlah ribuan tentu menjadi potensi wisatawan daerah yang dapat mengunjungi daerah-daerah wisata di seluruh wilayah Yogyakarta. Inilah yang perlu dikelola dengan sebaik-baiknya agar mereka menjadi orang bisa menjadi pemasar atau marketing ke saudara, teman-teman tempat daerah asal mereka kuliah/belajar.

\section{Data Identitas Pengunjung Wisata di Yogyakarta}

Penelitian yang melibatkan mahasiswa/wi yang sedang studi di perguruan tinggi di wilayah Yogyakarta sebagai responden untuk mengetahui analisis penilaian terhadap sejumlah obyek wisata saat atau pernah mereka kunjungi. Analisis ini dapat mengetahui penilaian kualitas dan kuantitas obyek wisata yang ada di wilayah Yogyakarta yang telah dikembangkan oleh stakeholder yang ada di Yogyakarta kemudian dinilai mereka sehingga respon kepuasaan pengunjung dapat diketahui.

Sampel penelitian dalam penelitian yang bersifat analisis ini berjumlah 45 mahasiswa sebagai responden dimana mereka berasal dari berbagai daerah khususnya dari luar Yogyakarta. Dengan data sejumlah responden diatas maka dapat dianalisis sebagai berikut :

Tabel 1. Data Karakteristik Mahasiswa

\begin{tabular}{|c|c|c|c|}
\hline Keterangan & Keterangan & Frekuensi & Persentase \\
\hline \multirow{3}{*}{$\begin{array}{l}\text { Jenis } \\
\text { Kelamin }\end{array}$} & Perempuan & 41 & $91,1 \%$ \\
\hline & Laki-Laki & 4 & $8,8 \%$ \\
\hline & Total & 45 & $100 \%$ \\
\hline \multirow[t]{5}{*}{ Usia } & 18 Tahun & 8 & $17,7 \%$ \\
\hline & 19 Tahun & 29 & $64,4 \%$ \\
\hline & 20 Tahun & 7 & $15,5 \%$ \\
\hline & 22 Tahun & 1 & $2,2 \%$ \\
\hline & Total & 45 & $100 \%$ \\
\hline
\end{tabular}

Melihat tabel 1 bahwa responden sebagai wisatawan yang berkunjung di beberapa obyek wisata di wilayah Daerah Istimewa Yogyakarta rata-rata berusia 18 tahun sebanyak $17,7 \%$ dan berusia 19 tahun sebanyak $64,4 \%$ dengan demikian usia tersebut maka usia anak-anak kuliah. Kemudian mayoritas yang berkunjung dibeberapa obyek wisata tersebut merupakan wisatawan berjenis kelamin perempuan yaitu sebanyak $91,1 \%$ dari responden yang diteliti dan hanya $8,8 \%$ yang berjenis kelamin lakilaki.

Dengan demikian mayoritas wisatawan yang berkunjung di obyek wisata di wilayah Yogyakarta adalah mahasiswa yang sedang menjalani pendidikan atau belajar di kampus di wilayah Yogyakarta. Jenis kelamin perempuan adalah responden yang paling banyak.

Tabel 2. Data Asal Daerah Mahasiswa

\begin{tabular}{clcc}
\hline No & \multicolumn{1}{c}{ Provinsi } & Frekuensi & Persentase \\
\hline 1 & $\begin{array}{l}\text { Nusa Tenggara } \\
\text { Barat }\end{array}$ & 8 & $17,7 \%$ \\
\hline 2 & Sulawesi Tengah & 6 & $13,3 \%$ \\
\hline 3 & Sulawesi Selatan & 5 & $11,1 \%$ \\
\hline 4 & Kalimantan Barat & 7 & $15,5 \%$ \\
\hline 5 & Kalimantan Utara & 1 & $2,2 \%$ \\
\hline 6 & Kalimantan & 6 & $13,3 \%$ \\
& Tengah & 3 & $6,6 \%$ \\
\hline 7 & Riau & 4 & $8,8 \%$ \\
\hline 8 & Sumatera Barat & 4 & $8,8 \%$ \\
\hline 9 & Sulawesi Selatan & 1 & $2,2 \%$ \\
\hline 10 & Maluku & 45 & $100 \%$ \\
\hline \multicolumn{2}{c}{ Total } & &
\end{tabular}

Sebagai obyek wisata yang bersifat alam dan budaya membuat Provinsi Yogyakarta banyak menjadi tujuan 
wisatawan luar daerah dan menjadikan wilayah ini sebagai tempat untuk menimba ilmu karena kualitas pendidikan sudah diakui oleh masyarakat. Melihat tabel diatas bahwa obyel wisata yang dikunjungi oleh wisatawan yang berlatar belakang mahasiswa yang kuliah di Yogyakarta kebanyakan dari daerah Nusa Tenggara Barat sebanyak $17,7 \%$ saat dilakukan penelitian. Data $15,5 \%$ wisatawan dari Kalimantan Barat serta 13,3\% dari Kalimantan Tengah dan Sulawesi Tengah. Dengan demikian mahasiswa yang berasal dari luar Jawa yang sedang berkuliah di Yogyakarta merupakan potensi orang yang berwisata diberbagai obyek wisata di wilayah Yogyakarta.

Tabel 3. Data Tentang Obyek Wisata yang Pernah Dikunjungi

\begin{tabular}{clcc}
\hline No & Obyek Wisata & Frekuensi & Persentase \\
\hline 1 & Candi Prambanan & 9 & $20 \%$ \\
\hline 2 & $\begin{array}{l}\text { Hutan Pinus } \\
\text { Mangunan }\end{array}$ & 16 & $35 \%$ \\
\hline 3 & Taman Sari & 3 & $6,6 \%$ \\
\hline 4 & Gua Jepang & 1 & $2,2 \%$ \\
\hline 5 & Pantai Cemara & 1 & $2,2 \%$ \\
\hline 6 & Pantai Indrayanti & 3 & $6,6 \%$ \\
\hline 7 & Kalibiru & 1 & $2,2 \%$ \\
\hline 8 & Waterpark & & \\
& (Jogya Bay dan & 1 & $2,2 \%$ \\
& Balong) & & \\
\hline 9 & Pantai Kukup & 4 & $8,8 \%$ \\
\hline 10 & Bukit Bintang & 1 & $2,2 \%$ \\
\hline 11 & Sungai Mudal & 1 & $2,2 \%$ \\
\hline 12 & Pantai Jengwok & 1 & $2,2 \%$ \\
\hline 13 & Bukit Muju & 1 & $2,2 \%$ \\
\hline 14 & Pantai Sepanjang & 2 & $4,4 \%$ \\
\hline 15 & Pantai Drini & 2 & $4,4 \%$ \\
\hline 16 & Malioboro & 17 & $37,7 \%$ \\
\hline 17 & Tugu & 2 & $4,4 \%$ \\
\hline 18 & Pantai Parangtritis & 18 & $40 \%$ \\
\hline 19 & Candi Sambisari & 1 & $2,2 \%$ \\
\hline 20 & Candi ljo & 1 & $2,2 \%$ \\
\hline 21 & Tebing Bresit & 1 & $2,2 \%$ \\
\hline 22 & Kaliadem & 2 & $4,4 \%$ \\
\hline 23 & Blue Lagoo n & 1 & $2,2 \%$ \\
\hline 24 & Alun-alun Selatan & 1 & $2,2 \%$ \\
\hline 25 & Merapi park & 2 & $4,4 \%$ \\
\hline 26 & Gumuk Pasir & 2 & $4,4 \%$ \\
\hline 27 & Pantai Sundak & 1 & $2,2 \%$ \\
\hline 28 & Pantai Baron & 2 & $4,4 \%$ \\
\hline 29 & Hutan $\quad$ Pinus & 2 & $4,4 \%$ \\
\hline & & & \\
\hline & & \\
\hline
\end{tabular}

\begin{tabular}{llcc}
\hline No & Obyek Wisata & Frekuensi & Persentase \\
\hline & Kragilan & & \\
\hline 30 & Sindupark & 1 & $2,2 \%$ \\
\hline 31 & Keraton & 1 & $2,2 \%$ \\
\hline 32 & Imogiri & 1 & $2,2 \%$ \\
\hline 33 & Alun-alun Utara & 1 & $2,2 \%$ \\
\hline 34 & Pantai depol & 1 & $2,2 \%$ \\
\hline 35 & Gua Selarong & 2 & $4,4 \%$ \\
\hline 36 & Hutang Pinus & 2 & $4,4 \%$ \\
& Pangger & & \\
\hline
\end{tabular}

Obyek wisata yang menjadi favorit para mahasiswa yang sedang berkuliah di Yogyakarta adalah wisata alam dan wisata belanja serta wisata pedestrian. Dalam data tersebut Pantai Parangtritis di Kabupaten Bantul masih menjadi incaran wisatawan untuk berkujung adapun datanya sebanyak $40 \%$. Kemudian kawasan malioboro juga menjadi faviorit mahasiswa sebagai wisatawan belanja dan kulineri yaitu sebanyak $37,7 \%$. Dari data tersebut wajar kalau obyek wisata alam seperti laut masih menjadi favorit wisatawan untuk berkunjung. Letak Pantai Parangtritis yang tidak jauh dari kota Yogyakarta ditunjang fasilitas jalan beserta aksesnya yang mudah dijangkau wajarlah menjadi obyek wisata yang selalu dikunjungi.

Kawasan Malioboro juga masih menjadi tempat berkunjung mahasiswa sebagai wisatawan yang ingin jalan-jalan atau berbelanja serta kulineri karena akses menuju relative dekat dengan tempat tinggal atau pondokkan sekitar kampus mereka sedang belajar di Yogyakarta.

Kawasan wisata alam yang baru dan masih bersih serta sejuk adalah wisata alam Hutan Pinus Mangunan di Kecamatan Dlingo Kabupaten Bantul; Kawasan yang ada didaerah pegunungan seribu itu menjadi favorit mahasiswa sebagai wisatawan yang senang dengan kawasan alam yang sejuk dan dingin. Data dari tabel 3 diatas bahwa sebanyak $35 \%$ wisatawan yang telah berkunjung ditempat tersebut. Meski dikawasan kecamatan Dlingo banyak obyek wisata alam seperti kebun buah mangunan serta hutan pinus pager namun hutan pinus Mangunana tetap menjadi favorit mahasiswa untuk berkunjung. Hal ini 
dikarenakan akses jalan yang mudah serta tidak jauh dari kampus mereka belajar.

\section{Tabel 4. Data Tentang Sumber Informasi dari Obyek Wisata}

\begin{tabular}{clcc}
\hline No & Asal Informasi & Frekuensi & Persentase \\
\hline 1 & Internet & 22 & $48 \%$ \\
\hline 2 & Teman & 18 & $40 \%$ \\
\hline 3 & Saudara & 3 & $6,6 \%$ \\
\hline 4 & Masyarakat & 1 & $2,2 \%$ \\
\hline 5 & Kampus & 1 & $2,2 \%$ \\
\hline 6 & lbu Kost & 1 & $2,2 \%$ \\
\hline 7 & Asal Sekolah & 1 & $2,2 \%$ \\
\hline
\end{tabular}

Para mahasiswa yang berkunjung ke obyek wisata di Yogyakarta mendapat informasi dari internet hal ini didapat dari $48 \%$ responden mengatakan bahwa media sosial dan internet sebagai sumber informasi dari obyek wisata yang akan dikunjungi. Faktor teman atau sahabat juga menjadi pengaruh orang untuk berkunjung ke suatu obyek wisata. Pada penelitian ini responden dikalangan mahasiswa mengatakan bahwa $40 \%$ wisatawan yang berkunjung di obyek wisata di wilayah Yogyakarta dikarenakan karena informasi teman yang telah berkunjung ke suatu obyek wisata tersebut.

Tabel 5. Data Tentang Frekuensi untuk Berkunjung Obyek Wisata

\begin{tabular}{cccc}
\hline No & Keterangan & Frekuensi & Persentase \\
\hline 1 & 1 & 19 & $42,2 \%$ \\
\hline 2 & 2 & 7 & $15,5 \%$ \\
\hline 3 & 3 & 8 & $17,7 \%$ \\
\hline 4 & 4 & 5 & $11,1 \%$ \\
\hline 5 & 5 & 1 & $2,2 \%$ \\
\hline 6 & $>5$ & 1 & $2,2 \%$ \\
\hline
\end{tabular}

Para mahasiswa yang melakukan kunjungan ke obyek wisata di wilayah Yogyakarta dihitung dalam jumlah kunjungan dinyatakan mereka baru pertama kali berkunjung di suatu obyek wisata tersebut. Hal ini diutarakan dari 19\% mereka baru satu kali berkunjung. Kemudian ada $17 \%$ menyatakan telah tiga kali berkunjung serta $15 \%$ responden yang menyatakan dua kali berkunjung. Dengan demikian bahwa mahasiswa luar Yogyakarta yang menempuh pendidikan di kota Yogyakarta hanya melakukan kunjungan ke obyek wisata ratarata 1-2 kali berkunjung.
Tabel 6. Data Tentang Kepuasaan Terhadap Pemandangan Alam pada Obyek Wisata Dikunjungi

\begin{tabular}{clcc}
\hline No & Keterangan & Frekuensi & Persentase \\
\hline 1 & Ya Memuaskan & 33 & $73,3 \%$ \\
\hline 2 & $\begin{array}{l}\text { Tidak } \\
\text { Memuaskan }\end{array}$ & 9 & $20,0 \%$ \\
\hline 3 & Ragu-ragu & 2 & $4,4 \%$ \\
\hline & Total & 45 & $100 \% \%$ \\
\hline
\end{tabular}

Untuk data kepuasaan terhadap obyek wisata terutama obyek wisata alam seperti pegunungan, pantai dan candi dinyatakan bahwa hampir $73 \%$ menyatakan puas dengan keindahaan alam dilokasi obyek wisata yang mereka kunjungi. Obyek wisata hutan mangunan misalnya bahwa wisatawan senang dengan alamnya yang masih alami dan banyak spot untuk digunakan berfoto ria. Kemudian pantai Parangtritis dan pantai selatan lainnya juga dinilai alamnya masih indah untuk dikunjunngi. Adapun data yang menyatakan tidak puas dengan alam pemandangannya hanya $20 \%$ hal ini mungkin obyek wisata yang dikunjungi suasananya sudah tidak alammi karena banyak pedagang atau gersang dan lain-lain.

Tabel 7. Data Tentang Kepuasaan Ada dan Tidaknya Souvenir/Merchandise yang Tersedia pada Obyek Wisata yang Dikunjungi

\begin{tabular}{clcc}
\hline No & Keterangan & Frekuensi & Persentase \\
\hline 1 & Ya Memuaskan & 39 & $86,6 \%$ \\
\hline 2 & Tidak & 5 & $11,1 \%$ \\
& Memuaskan & & $100 \%$ \\
\hline 3 & Ragu-ragu & 0 & $100 \% \%$ \\
\hline \multicolumn{2}{l}{ Total } & 45 & apabila itu
\end{tabular}
mahasiswa yang berkunjung ke suatu obyek wisata pasti yang akan dicari adalah souvenir atau merchandise. Sebanyak 39\% responden menyatakan bahwa souvenir yang ada di obyek wisata di wilayah Yogyakarta memuaskan artinya mereka mencari pernakpernik souvenir yang dibeli sebagai kenangan bahwa mereka telah berkunjung. Obyek wisata yang banyak souvenir biasanya obyek wisata pantai. Responden yang menyatakan tidak puas hanya $11,1 \%$ saja hal ini dikarenakan obyek wisata tidak 
ada yang menjual souvenir. Hal ini mungkin dikarenakan obyek wisata tersebut baru dibuka atau belum dikenal dikalangan wisatawan seperti Hutan Pinus Kragilan atau kalau pantai seperti pantai Jengwok atau sepanjang di Kabupaten Gunung Kidul.

Tabel 8. Data Tentang Kepuasaan Dengan Fasilitas yang Tersedia di Obyek Wisata Tersebut

\begin{tabular}{llcc}
\hline No & $\begin{array}{l}\text { Keterangan Fasiltas } \\
\text { di Obyek wisata }\end{array}$ & Frekuensi & Persentase \\
\hline 1. & Bangku Tempat Duduk & 27 & $60 \%$ \\
\hline 2. & $\begin{array}{l}\text { Tempat Berbelanja } \\
\text { Makanan }\end{array}$ & 2 & $4,4 \%$ \\
\hline 3. & Tempat Bermain Anak & 1 & $2,2 \%$ \\
\hline 4. & Tempat Parkir & 7 & $15,5 \%$ \\
\hline 5. & Spot Foto & 3 & $6,6 \%$ \\
\hline 6. & Mushola & 5 & $11,1 \%$ \\
\hline
\end{tabular}

Sebuah obyek wisata akan dinilai baik jika ditunjang fasilitas yang lengkap untuk memberi rasa nyaman bagi wisatawan. Pada obyek wisata di wilayah Yogyakarta beberapa fasilitas sudah dilengkapi untuk memberi kenyaman wisatawan. Dalam penelitian ini mahasiswa luar jawa memberi penilaian untuk sarana-prasarana yang mereka nilai baik sehingga memberi kenyamanan mereka seperti kepuasaan pada tempat duduk atau bangku untuk santai menikmati pemandangan. Data respondeng mengatakan ada $60 \%$ puas ada fasilitas tempat duduk. Kemudian tempat parkir juga dinilai baik hal dikatakan $15,5 \%$ responden. Tempat ibadah dinilai $11,1 \%$ responden juga baik. Ketersediaan spot foto juga dinilai baik menurut $6,6 \%$ responden.

Tabel 9. Data Tentang Pernyataan

Kepuasan Dengan Pelayanan

Restoran/Rumah Makan di Obyek Wisata

\begin{tabular}{cccc}
\hline No & Keterangan & Frekuensi & Persentase \\
\hline 1 & Ya Memuaskan & 34 & $75,5 \%$ \\
\hline 2 & Tidak Memuaskan & 4 & $8,8 \%$ \\
\hline 3 & Ragu-ragu & 7 & $15,5 \%$ \\
\hline & Total & 45 & $100 \%$ \\
\hline
\end{tabular}

Obyek wisata tanpa kulineri tidak lengkap, untuk itu obyek wisata di wilayah Yogyakarta banyak sekali penawaran untuk ketersediaan rumah makan atau kulineri. Wisatawan yang berasal dari mahasiswa luar jawa mengatakan puas dengan pelayanan restaurant atau rumah makan hal dikatakan dari $75,5 \%$ dan hanya $8,8 \%$ yang menyatakan tidak puas mungkin dikarenakan faktor harga atau daftar menu makanan yang disajikan.

Tabel 10. Data Tentang Ketersediaan Jalan Menuju Lokasi Obyek Wisata yang Mudah Ditempuh

\begin{tabular}{cccc}
\hline No & Keterangan & Frekuensi & Persentase \\
\hline 1 & Ya Memuaskan & 34 & $75,5 \%$ \\
\hline 2 & Tidak Memuaskan & 3 & $6,6 \%$ \\
\hline 3 & Ragu-ragu & 7 & $15,5 \%$ \\
\hline & Total & 45 & $100 \%$ \\
\hline
\end{tabular}

Ketersediaan jalan menuju obyek wisata di wilayah Yogyakarta dinilai wisatwan sangat memuaskan hal ini yang dikatakan oleh $75,5 \%$ responden. Hal ini disebabkan lokasi wisata yang relative dekat dengan kampus mereka belajar serta pondokkan mereka tinggal. Untuk obyek wisata alam yang jauh dan baru dibuka kadang dinilai tidak memuaskan menurut $6,6 \%$ responden.

\section{Tabel 11. Data Tentang Kualitas Jalan \\ Menuju Lokasi Obyek Wisata yang Dalam Kondisi Baik}

\begin{tabular}{cccc}
\hline No & Keterangan & Frekuensi & Persentase \\
\hline 1 & Ya Memuaskan & 33 & $73,3 \%$ \\
\hline 2 & Tidak Memuaskan & 3 & $6,6 \%$ \\
\hline 3 & Ragu-ragu & 8 & $17,7 \%$ \\
\hline & Total & 45 & $100 \%$ \\
\hline
\end{tabular}

Masalah kualitas jalan dikatakan responden memuaskan $73,3 \%$ namun hanya $6,6 \%$ saja yang menyatakan tidak memuaskan hal ini disebabkan obyek wisata alam yang masih baru dibuka dan jalannya masih berbatu dan curam menuju lokasinya.

Tabel 12. Data Petunjuk Jalan yang

Tersedia Sepanjang Obyek Wisata

\begin{tabular}{cccc}
\hline No & Keterangan & Frekuensi & Persentase \\
\hline 1 & Ya Memuaskan & 42 & $93,3 \%$ \\
\hline 2 & Tidak Memuaskan & 2 & $4,4 \%$ \\
\hline 3 & Ragu-ragu & 1 & $2,2 \%$ \\
\hline & Total & 45 & $100 \%$ \\
\hline
\end{tabular}

Ketersediaan petunjuk jalan menuju obyek wisata sangat berpengaruh terhadap kepuasaan wisatawan yang akan berkunjung 
ke suatu obyek wisata di wilayah Yogyakarta. Wisatawan dari luar Yogyakarta khususnya mahasiswa dari luar Jawa sangat berharap kepada pemerintah propinsi dan kabupaten yang mempunyai obyek wisata untuk selalu menyediakan petunjuk informasi tempat obyek wisata khususnya petunjuk jalan menuju obyek wisata. Dari tabel 12 bahwa wisatawan merasa puas tentang ketersediaan petunjuk jalan menuju obyek wisata hal ini menurut pernyataan 93,3\% responden. Namun ada $4,4 \%$ yang merasa tidak puas, hal ini dikarenakan ada obyek wisata baru seperti wisata alam pegunungan dan pantai. Dan obyek wisata tersebut yang membuka warga yang ada diobyek wisata tersebut dan petunjuk jalannya masih sederhana sehingga membingungkan wisatawan yang akan berkunjung.

Tabel 13. Data Tentang Keramahan

Masyarakat Sekitar Obyek Wisata

\begin{tabular}{cccc}
\hline No & Keterangan & Frekuensi & Persentase \\
\hline 1 & Ya Memuaskan & 41 & $91,1 \%$ \\
\hline 2 & Tidak Memuaskan & 4 & $2,2 \%$ \\
\hline 3 & Ragu-ragu & 0 & $0 \%$ \\
\hline & Total & 45 & $100 \%$ \\
\hline
\end{tabular}

Kepuasaan wisatawan sangat dipengaruhi oleh sambutan warga yang melayani dengan keramahaan dan siap membantu. Menurut $91,1 \%$ responden menyakatan kepuasaannya dengan faktor keramah-tamahan warga atai penduduk yang ada di lingkungan obyek wisata saat mereka berkunjung dan hanya $2,2 \%$ saja yang mengatakan tidak memuaskan.

Tabel 14. Data Tentang Kepuasan Kebersihan di Lingkungan Obyek Wisata

\begin{tabular}{cccc}
\hline No & Keterangan & Frekuensi & Persentase \\
\hline 1 & Ya Memuaskan & 34 & $75,5 \%$ \\
\hline 2 & Tidak Memuaskan & 5 & $11,1 \%$ \\
\hline 3 & Ragu-ragu & 6 & $13,3 \%$ \\
\hline & Total & 45 & $100 \%$ \\
\hline
\end{tabular}

Faktor kebersihan sangat berpengaruh terhadap kunjungan wisatawan karena akan memberi dampak kenyaman dan kepuasaan saat berkunjung. Wajah suatu obyek wisata akan selalu dinilai dari kebersihan dan kenyaman pengunjung wisata. Dari data peneliti para mahasiswa yang menjadi wisatawan daerah saat berkunjung ke suatu obyek wisata di wilayah Yogyakarta mereka mengatakan merasa puas dengan faktor kebersihan hal ini disampaikan oleh 75,5\% responden. Sedangkan11,1\% menyatakan tidak puas hal ini dikarenakan saat wisatawan berkunjung disuatu obyek wisata sarana prasarana kebersihan masih minim, biasanya di obyek wisata pantai.

Tabel 15. Data Tentang Kepuasan Dengan Keamanan Sekitar Obyek Wisata

\begin{tabular}{cccc}
\hline No & Keterangan & Frekuensi & Persentase \\
\hline 1 & Ya Memuaskan & 39 & $86,6 \%$ \\
\hline 2 & Tidak Memuaskan & 1 & $2,2 \%$ \\
\hline 3 & Ragu-ragu & 5 & $11,1 \%$ \\
\hline & Total & 45 & $100 \%$ \\
\hline
\end{tabular}

Banyak tidaknya wisatawan berkunjung ke obyek wisata sangat ditentukan oleh faktor keamanan yang ada di obyek wisata tersebut. Kota Yogyakarta yang sudah dikenal dengan keramahtamahnya menjadikan obyek wisata dijadikan tujuan wisatawan domestic maupun internasional. Hal ini dinyatakan oleh $86,6 \%$ responden menyatakan puas karena keamanan terhadap obyek wisata di wilayah Yogyakarta. Aman disini tidak hanya aman dari gangguan dari kriminal namun aman dari resiko kecelakaan di obyek wisata seperti di pantai selatan wilayah Bantul Kidul dan Bantul.

Tabel 16. Data Tentang Kepuasan Dengan Harga/Biaya yang Dikeluarkan Selama di Obyek Wisata

\begin{tabular}{cccc}
\hline No & Keterangan & Frekuensi & Persentase \\
\hline 1 & Ya Memuaskan & 38 & $84,4 \%$ \\
\hline 2 & Tidak Memuaskan & 4 & $8,8 \%$ \\
\hline 3 & Ragu-ragu & 3 & $6,6 \%$ \\
\hline & Total & 45 & $100 \%$ \\
\hline
\end{tabular}

Ramai tidaknya suatu obyek wisata di wilayah Yogyakarta sangat ditentukan oleh harga atau biaya yang dikeluarkan wisatawan saat berkunjung di obyek wisata tersebut. Ongkos biaya seperti tiket masuk, harga makan-minum, souvenir atau penggunaan sarana-prasarana sangat diperhatikan oleh wisatawan seperti kasusunya kalau wisatawan dari mahasiswa 
yang berkunjung. Menurut data penelitian bahwa $84,4 \%$ respondeng menyatakan puas tentang harga atau biaya yang dikeluarkan saat berkunjung, namun ada $8,8 \%$ menyatakan tidak puas dan 6,6 respondeng menyatakan ragu-ragu tentang hal tersebut. Ketidakpuasaan disebabkan masih ada penjual makanan yang memberi tariff mahal saat liburan sekolah atau akhir tahun, biasanya di obyek wisata Malioboro.

Tabel 17. Data Tentang Kepuasan Dengan Harga Makanan di Obyek Wisata

\begin{tabular}{cccc}
\hline No & Keterangan & Frekuensi & Persentase \\
\hline 1 & Ya Memuaskan & 32 & $71,1 \%$ \\
\hline 2 & Tidak Memuaskan & 9 & $20 \%$ \\
\hline 3 & Ragu-ragu & 4 & $8,8 \%$ \\
\hline & Total & 45 & $100 \%$ \\
\hline
\end{tabular}

Kepuasaan wisatawan khususnya mahasiswa yang berkunjung ke suatu obyek wisata di wilayah Yogyakarta menilai tentang masalah makanan atau kulineri yang selalu dicari selama berkunjung. Responden mengatakan tentang harga makanan di obyek bagi mereka menyatakan memuaskan hal dikatakan $71,1 \%$ responden. Dengan harga yang wajar mereka merasa puas. Namun ada yang mengatakan tidak puas sebanyak $20 \%$ responden, ini dikarenakan saat hari libur panjang ada obyek wisata yang menaikkan tariff tinggi.

Tabel 18. Data Tentang Membicarakan

Kepuasan dan Pengalaman Positif

Selama di Obyek Wisata Ini Kepada

Orang Lain

\begin{tabular}{cccc}
\hline No & Keterangan & Frekuensi & Persentase \\
\hline 1 & Ya Memuaskan & 41 & $91,1 \%$ \\
\hline 2 & Tidak Memuaskan & 4 & $8,8 \%$ \\
\hline 3 & Ragu-ragu & 0 & $0 \%$ \\
\hline & Total & 45 & $100 \%$ \\
\hline
\end{tabular}

Para mahasiswa luar jawa yang menjadi wisatawan di obyek wisata wilayah Yogyakarta mengatakan bahwa mereka merasa puas dan menjadikan pengalaman positif hidupnya selama kuliah di Yogyakarta. Hal ini dikatakan 91,1\% responden mereka membicarakan kepuasaan dan pengalaman positifnya selama mengunjungi obyek wisata di Yogyakarta. Hanya $8,8 \%$ responden saja yang tidak merasa puas dan mempunyai pengalaman positif selama berkunjung ke suatu obyek wisata di wilayah Yogyakarta.

Tabel 19. Data Tentang

Merekomendasikan Obyek Wisata Ini Kepada Orang Lain

\begin{tabular}{cccc}
\hline No & Keterangan & Frekuensi & Persentase \\
\hline 1 & Ya Memuaskan & 43 & $95,5 \%$ \\
\hline 2 & Tidak Memuaskan & 1 & $2,2 \%$ \\
\hline 3 & Ragu-ragu & 1 & $2,2 \%$ \\
\hline & Total & 45 & $100 \%$ \\
\hline
\end{tabular}

Saat berkunjung ke berbagai obyek wisata di wilayah Yogyakatya mahasiswa yang berasal dari luar jawa karena memperoleh kepuasaan dan pengalamanan positifnya tentunya mereka akan merekomendasikan ke orang lain. Sebanyak $95,5 \%$ responden menyatakan akan merekomendasikan tentang obyek wisata yang pernah mereka kunjungi ke orang lain.

Tabel 20. Data Tentang Akan Mengunjungi Kembali Obyek Wisata Ini Suatu Hari Nanti

\begin{tabular}{cccc}
\hline No & Keterangan & Frekuensi & Persentase \\
\hline 1 & Ya Memuaskan & 43 & $95,5 \%$ \\
\hline 2 & Tidak Memuaskan & 1 & $2,2 \%$ \\
\hline 3 & Ragu-ragu & 1 & $2,2 \%$ \\
\hline & Total & 45 & $100 \%$ \\
\hline
\end{tabular}

Kepuasaan pengunjung dalam hal ini para mahasiswa luar jawa yang sedang kuliah di Yogyakarta ditandai dengan pernyataan tentang mereka berkeinginan kembali untuk mengunjungi obyek wisata yang pernah mereka kunjungi. Pernyataan tersebut dinyatakan oleh $95,5 \%$ respondeng mereka suatu saat akan berkunjung kembali ke obyek wisata di wilayah Yogyakarta yang pernah mereka kunjungi.

Pengembangan pariwisata di Provinsi Daerah Istimewa Yogyakarta dari tahun ke tahun mengalami kemajuan hal ini tampak pembangunan pariwisata disetiap daerah kabupaten/kota di wilayah provinsi ini memberi hasil terhadap kunjungan wisatawan domestic maupun internasional. Stratego pengembangan pariwisata yang didukung oleh pemerintah pusat, daerah serta swasta dan masyarakat membuat pariwisata Provinsi Yogyakarta setiap tahun 
mengalami peningkatan. Sebagai kota budaya dan pendidikan kota Yogyakarta setiap tahun selalu mengalami kenaikan dalam penerimaan pelajar dan mahasiswa yang ingin bersekolah di kota ini. Daya tarik sebagai kota pendidikan ditunjang dengan kota budaya serta daerah destinasi wisata menjadikan pelajar dan mahasiswa yang sedang belajar di kota ini menjadi asset berharga bagi pemerintah karena mereka adalah potensi wisatawan yang selalu akan berkunjung ke berbagai obyek wisata di wilayah Yogyakarta.

Potensi wisata di wilayah Yogyakarta yang kaya dengan alam wisata seperti pantai, gunung dan sungai serta lain-lain menjadikan pemerintah selalu serius mengembangkan obyek wisata yang dimiliki masing-masing kabupaten/kota di wilayah Yogyakarta. Wisatawan yang sering berkunjung di wilayah Yogyakarta kebanyakan wisatawan pelajar atau mahasiswa yang sering mengadakan studi banding kemudian dilanjutkan dengan berkunjung ke obyek wisata yang ada di wilayah Yogyakarta. Begitu juga wisatawan yang berasal dari mahasiswa atau pelajar yang sedang duduk kuliah di Perguruan Tinggi Swasta atau Negeri di wilayah Yogyakarta sangat potensi menjadi asset untuk menumbuhkan ekonomi karena ada obyek wisata yang sudah atau belum berkembang.

\section{KESIMPULAN}

Berdasarkan uraian diatas maka penelitian tentang analisis penilaian mahasiswa luar jawa sebagai wisatawan terhadap pengembangangan wisata di berbagai obyek wisata di Daerah Istimewa Yogyakarta dapat disimpulkan sebagai berikut :

1. Mahasiswa luar jawa yang kuliah di Yogyakarta sebagai wisatawan menjadi aset ekonomi untuk pertumbuhan pariwisata di Yogyakarta.

2. Mahasiswa luar jawa yang kuliah di Yogyakarta sebagai wisatawan menilai pengembangan obyek wisata sudah baik hal ini dibuktikan dengan bahwa : a. Fasilitas Pariwisata di obyek wisata di wilayah Yogyakarta sudah baik

b. Akses jalan menuju obyek wisata sudah di nilai baik

c. Penunjuk jalan di lokasi obyek wisata sudah di nilai baik

3. Mahasiswa luar jawa yang kuliah di Yogyakarta sebagai wisatawan merasa puas terhadap pelayanan di lokasi obyek wisata seperti pelayanan restoran, keamanan dan kebersihan sehingga wisatawan menjadi betah dan nyaman di obyek wisata.

4. Mahasiswa luar jawa yang kuliah di Yogyakarta sebagai wisatawan menilai harga makanan serta tiket atau tarif masuk obyek wisata di Wilayah Yogyakarta masih wajar artinya masih terjangkau oleh mereka.

5. Mahasiswa luar jawa yang kuliah di Yogyakarya sebagai wisatawan merasa mendapat pengalaman dan kesan yang positif dan akan merekomendasikan ke orang lain untuk dapat berkunjung ke Yogyakarta yang banyak obyek wisata.

Dari kesimpulan diatas, maka peneliti menganjurkan sebagai saran-saran kepada pemangku di wilayah Yogyakarta baik dari Pemerintah, Swasta dan Masyarakat dalam mengembangkan obyek wisata di wilayah Yogyakarta untuk :

1. Selalu mempertahankan pelayanan ke wisatawan yang berkunjung di obyek wisata di wilayah Yogyakarta secara kuantitas dan kualitas sehingga mereka akan menilai kesan yang baik terhadap pelayanan yang diberikan.

2. Selalu memberikan pembinaan kepada stokeholder agar sadhar wisata harus selalu dimunculkan dalam pelayanan kepada wisatawan.

3. Selalu meningkatkan pengembangan obyek wisata khususnya kegiatan pemasaran bahwa Yogyakarta selain kota pendidikan dan budaya bahwa Yogyakarta sebagai destinasi wisata yang aman dan nyaman untuk selalu dikunjungi. 
DAFTAR PUSTAKA

Burton, R. (1995). Travel Geography. London : Pitman Publishing

Gamal, Suwantoro. (1997). Dasar-Dasar Pariwisata. Yogyakarta: Penerbit Andi.

Ismayanti. (2010). Pengantar Pariwisata. Jakarta: PT. Gramedia Widiasarana Indonesia.

Marpaung, Happy, (2002). Pengetahuan Pariwisata Edisi Revisi. Bandung: Alfabeta.

Pendit, Nyoman, S. (1986). Ilmu Pariwisata. Jakarta: Pradnya Paramita.

Rangkuti. Freddy (2003). Analisis SWOT Teknik Membedah Kasus Bisnis. Jakarta: Gramedia Pustaka Utama.
Undang-Undang Kepariwisataan Nomor 9 Tahun 1990 Tentang Kepariwisataan. Jakarta.

Undang-Undang Republik Indonesia Nomor 10 Tahun 2009 Tentang Kepariwisataan. Jakarta.

Wardiyanta. (2006). Metode Penelitian Pariwisata. Yogyakarta: Andi Offset.

Yoeti, Oka A. (1996). Pengantar Ilmu Pariwisata. Bandung: Angkasa.

Yoeti, Oka A. (2005). Perencanaan Strategi Pemasaran Daerah Tujuan Wisata. Jakarta: PT. Pradnya Paramita. 